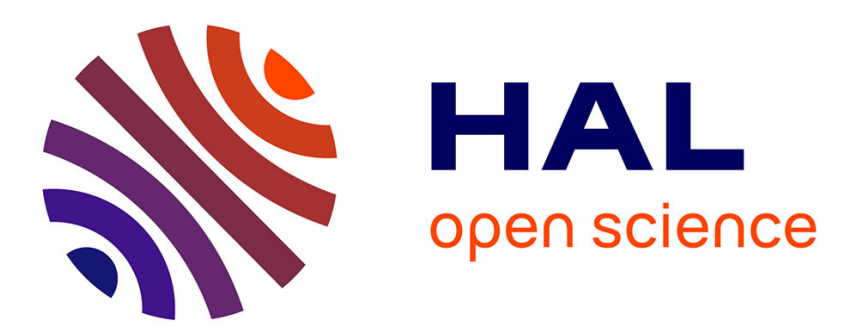

\title{
Brine-induced mortality of non-indigenous invertebrates in residual ballast water
}

Johanna N. Bradie, Sarah A. Bailey, Gerard van Der Velde, Hugh J. Macisaac

\section{To cite this version:}

Johanna N. Bradie, Sarah A. Bailey, Gerard van Der Velde, Hugh J. Macisaac. Brine-induced mortality of non-indigenous invertebrates in residual ballast water. Marine Environmental Research, 2010, 70 (5), pp.395. 10.1016/j.marenvres.2010.08.003 . hal-00631698

\section{HAL Id: hal-00631698 https://hal.science/hal-00631698}

Submitted on 13 Oct 2011

HAL is a multi-disciplinary open access archive for the deposit and dissemination of scientific research documents, whether they are published or not. The documents may come from teaching and research institutions in France or abroad, or from public or private research centers.
L'archive ouverte pluridisciplinaire HAL, est destinée au dépôt et à la diffusion de documents scientifiques de niveau recherche, publiés ou non, émanant des établissements d'enseignement et de recherche français ou étrangers, des laboratoires publics ou privés. 


\section{Accepted Manuscript}

Title: Brine-induced mortality of non-indigenous invertebrates in residual ballast water

Authors: Johanna N. Bradie, Sarah A. Bailey, Gerard van der Velde, Hugh J. Maclsaac

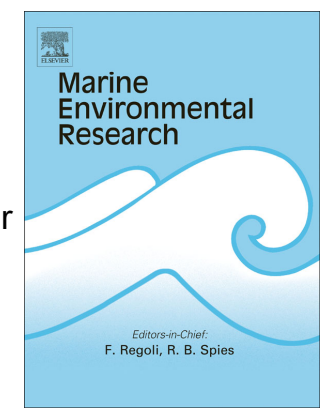

PII:

S0141-1136(10)00118-2

DOI: 10.1016/j.marenvres.2010.08.003

Reference: MERE 3469

To appear in: Marine Environmental Research

Received Date: 16 November 2009

Revised Date: 21 April 2010

Accepted Date: 14 August 2010

Please cite this article as: Bradie, J.N., Bailey, S.A., van der Velde, G., Maclsaac, H.J. Brine-induced mortality of non-indigenous invertebrates in residual ballast water, Marine Environmental Research (2010), doi: 10.1016/j.marenvres.2010.08.003

This is a PDF file of an unedited manuscript that has been accepted for publication. As a service to our customers we are providing this early version of the manuscript. The manuscript will undergo copyediting, typesetting, and review of the resulting proof before it is published in its final form. Please note that during the production process errors may be discovered which could affect the content, and all legal disclaimers that apply to the journal pertain. 
1 Title: Brine-induced mortality of non-indigenous invertebrates in residual ballast water 2

3 Authors: Johanna N. Bradie ${ }^{a,}$, Sarah A. Bailey ${ }^{\mathrm{b}, a}$, Gerard van der Velde ${ }^{\mathrm{c}, \mathrm{d}}$, Hugh J. $4 \quad$ Maclsaac $^{\mathrm{a}}$

${ }^{a}$ Great Lakes Institute for Environmental Research, University of Windsor,

401 Sunset Avenue, Windsor, ON, N9B 3P4; E-mail address: hughm@uwindsor.ca (H.J. Maclsaac)

${ }^{\mathrm{b}}$ Great Lakes Laboratory for Fisheries and Aquatic Sciences, Fisheries and Oceans Canada, 867 Lakeshore Road, Box 5050, Burlington, ON, L7R 4A6; E-mail address: sarah.bailey@dfo.mpo.gc.ca (S.A. Bailey)

${ }^{\mathrm{c}}$ Radboud University Nijmegen, Institute for Water and Wetland Research, Department of Animal Ecology and Ecophysiology, Heyendaalseweg 135, 6525 AJ Nijmegen, The Netherlands; E-mail address: g.vandervelde@science.ru.nl (G. van der Velde)

${ }^{d}$ Netherlands Centre for Biodiversity Naturalis, P.O. Box 9517, 2300 RA Leiden, The Netherlands

*Corresponding author. Tel.: +1 5143981833 ; fax: +1 5143985069.

E-mail address: johannabradie@hotmail.com (J.N. Bradie). 


\section{Abstract}

All transoceanic vessels entering the Great Lakes are required to manage ballast water and ballast tank residuals with ballast water exchange and tank flushing, respectively. While these management procedures effectively reduce the density and richness of biota in ballast waters and thereby reduce the risk of transferring nonindigenous species, some ships are unable to uniformly manage all tanks. Laboratory experiments were conducted to evaluate sodium chloride brine as an emergency treatment for ballast tanks with non-compliant residuals. Invertebrate communities collected from i) Detroit River, ii) exchanged ballast tanks arriving in the Great Lakes, and iii) North Sea ports, were exposed to a range of brine concentrations (15\%०-115\%o) until complete mortality was reached. Results indicate that a one-hour exposure to $115 \%$ o brine is a broadly effective treatment ( $>99.9 \%$ mortality) regardless of treatment temperature, taxonomic group, or species' source habitat salinity. A median of $0.00 \%$ (range $0.00-5.33$ ) of individuals are expected to survive treatment and the expected number of viable individuals released after treatment is within Canadian and proposed international discharge standards. Before implementation, validation with ship-scale trials is recommended.

Keywords: ballast water treatment; Great Lakes; non-indigenous species; sodium chloride brine; acute toxicity; zooplankton; salinity; introduced species

\section{Prepared for submission to Marine Environmental Research}




\section{Introduction}

Ballast water is utilized to control the trim, stability and stresses on operational ships that lack cargo. Worldwide, shipping operations move 10 billion $\mathrm{m}^{3}$ of ballast water and the biota contained therein annually (Rigby et al., 1999). Ballast water transfer provides a potent mechanism for dispersal of aquatic biota to locations far more distant than natural mechanisms alone could effect (Locke et al., 1993; Minton et al., 2005) and contributes significantly to non-indigenous species (NIS) introductions to aquatic systems globally (Carlton, 1985; Maclsaac et al., 2002).

Ships entering the Laurentian Great Lakes are effectively required to replace ballast water with mid-ocean seawater by exchanging full tanks or flushing residuals. Ballast water exchange and flushing reduce the risk of spreading NIS, particularly between freshwater regions, through a combination of purging and osmotic stress (see Gray et al., 2007; Santagata et al., 2008). However, at least $4 \%$ of ballast tanks in transoceanic vessels arriving to the Great Lakes in 2007 were non-compliant with ballast management regulations (120 tanks of 2867 inspected; M.G. Deneau, Fisheries and Oceans Canada, unpubl. results). Although ships with non-compliant ballast water have the choice to retain non-compliant ballast water on board for the duration of their Great Lakes' operations, or to return to sea to complete ballast exchange and/or tank flushing, a rapid and effective back-up treatment is highly desirable to minimize ship delays. As the majority of ships' ballast tanks contain only residual ballast water at entry to the Great Lakes, adequate treatment of tank residuals is a high priority.

The addition of sodium chloride $(\mathrm{NaCl})$ brine, herein referred to as brine, has been proposed as a cost-effective, readily-available treatment for management of non- 
compliant residual ballast water (Jenkins, 2007). A feasibility study indicated that brine could be easily applied to ballast tanks at port through the ship's sounding tube and that short-term exposure of ballast tanks to high salinity brine should not cause undue corrosion (Jenkins, 2007). In practice, because most ships will load ballast water into tanks at their first port-of-call in the Great Lakes, brine treatment of residual ballast could only be applied for a short time interval in some cases. As a result, an examination of the acute toxicity of brine exposure to aquatic invertebrates that are, or may be, transported by ship's ballast water is warranted.

As seawater ( $\geq 30 \%$ o salinity) used in current ballast management practices is effective in reducing the viability of fresh- and brackish-water taxa through osmotic stress, brine ( $>230 \%$ ) is expected to be at least as effective as current ballast management if the final salinity concentration is optimized for the duration of exposure. Altering the salinity of the surrounding environment can induce changes in the activity rate, internal volume, volume regulation, internal osmotic concentration, internal ionic content, ionic regulation, respiration rate, and oxygen requirements of aquatic organisms (Schlieper, 1971, Hart et al., 1991). A large and rapid increase in salinity is expected to disrupt the aforementioned processes resulting in mortality of ballastdwelling invertebrates. Furthermore, brine, which is manufactured from rock salt, differs substantially in ionic composition from natural ocean water, having $250 \%$ more sodium, chloride, calcium and strontium and $<20 \%$ of the potassium and magnesium found in natural ocean water (Turekian, 1968; Hovanec and Coshland, 2004; J.N. Bradie, unpubl. results). A high concentration of salts in an "unnatural" balance should cause 
mortality in aquatic taxa, and in fact, studies have shown that acute tolerance to $\mathrm{NaCl}$ is usually lower than acute tolerance to natural or artificial seawater (Kefford et al., 2004). Here the acute toxicity of $\mathrm{NaCl}$ brine exposure to aquatic invertebrates is examined in vitro. Addition of brine at high concentrations, for short time periods (i.e., hours), is expected to be the most feasible treatment application under typical operational schedules (Jenkins, 2007). As the regulatory standard for treatment using ballast water exchange is at least $95 \%$ volumetric exchange of ballast with a final salinity of $30 \%$, we aim to determine the brine concentration required to exterminate at least $95 \%$ of aquatic invertebrates contained in ballast water, given a short duration of exposure. While Santagata et al. (2009) determined that a one hour exposure to $110 \%$ brine was sufficient to cause $95 \%$ mortality, they conducted species-specific trials with only 25 species. In order to understand the efficacy of brine treatment more comprehensively, trials are conducted with diverse invertebrate communities collected from marine, freshwater and brackish-water habitats. We examine the effect of brine concentration, exposure time, treatment temperature, habitat salinity, and taxonomic affiliation on treatment efficacy to ensure that results are sufficiently robust to be applicable to all incoming vessels to the Great Lakes.

\section{Materials and methods}

\section{1 Collection of samples}

Invertebrates were collected in the field using vertical plankton net tows $(53 \mu \mathrm{m})$ and rinsed from the plankton net cod end into $25 \mathrm{~L}$ unfiltered site water for transport to the laboratory. Ambient salinity and temperature of site water were measured at the time of collection using a YSI 556 multi-parameter instrument (YSI Incorporated, Yellow 
110 Springs, $\mathrm{OH}$, USA) or digital thermometer and digital refractometer. Ambient site

111 salinities ranged from $0-39 \%$ and temperatures ranged from $5.0-24.2^{\circ} \mathrm{C}$. An extra $25 \mathrm{~L}$ of

112 ambient site water was collected for each trial and filtered (GF/F Whatman filter, $0.7 \mu \mathrm{m}$

113 pore size) to remove organisms and other organic matter for later dilution of brine to

114 pre-determined test concentrations.

115 Collection sites were: i) exchanged ballast tanks of five ships arriving in the Great

116 Lakes between July and November 2007; ii) the Detroit River, collected between August

1172007 and May 2008; and iii) the North Sea ports of Rotterdam, Antwerp and Bremen,

118 with collections made between July and August 2008. One additional sample collected

119 from the Waal River, the main distributary in the Rhine delta, at Nijmegen, The

120 Netherlands, is treated herein as a North Sea sample. North Sea taxa were of

121 significant interest because there is high shipping traffic between this region and the

122 Great Lakes (Ricciardi and Maclsaac, 2000; Colautti et al., 2003) and because similar

123 climatic conditions make it probable that individuals from North Sea ports will tolerate

124 the abiotic conditions of Great Lakes' ports (Reid and Orlova, 2002). In addition, tidal

125 salinity fluctuations in North Sea ports result in invertebrate assemblages that are at

126 least moderately tolerant of salinity changes (Barnes, 1994), so they should be a

127 conservative indicator of brine treatment efficacy. Slight variations in methodology

128 occurred during trials for each site, and are described below as ballast tank, Detroit

129 River, and North Sea experiments, respectively.

130

$131 \quad 2.2 \mathrm{NaCl}$ brine exposure experiments 
Since most aquatic invertebrates are essentially thermo-conformers, temperature changes directly alter their metabolic rate, thereby affecting their ability to osmo-

134 regulate in hyperosmotic salinities (Kinne, 1963, Schlieper, 1971). Brine treatment

135 efficacy was examined at exposure temperatures of $11^{\circ} \mathrm{C}$ and $22^{\circ} \mathrm{C}$ to investigate 136 efficacy throughout the shipping season. These temperatures were chosen based on

137 ballast tank temperatures measured during sample collection in August and December

138 for vessels entering the Great Lakes. North Sea experiments were conducted only at

$13922^{\circ} \mathrm{C}$ since there was no significant difference attributed to temperature after analyzing

140 results from ballast tank and Detroit River trials (see 3.3). Brine treatment

141 concentrations were chosen based on preliminary trials and findings of a brine

142 treatment feasibility study (Jenkins, 2007). Ballast tank taxa were exposed to brine

143 concentrations of $60 \%$, $77 \%$, and $115 \%$ o as recommended by Jenkins (2007). In

144 preliminary trials, Detroit River invertebrates displayed high mortality after exposure to

$14560 \%$ obrine, so Detroit River samples were subsequently tested at $15 \%$, $30 \%$, and $60 \%$.

146 In contrast, North Sea taxa were exposed to brine concentrations of $77 \%$ and $115 \%$,

147 since high variability in efficacy was observed after one hour exposure to $60 \%$ o brine

148 during ballast tank trials (see 3.2). The number of trials for each brine concentration and

149 temperature is summarized in Table 1. A total of 17 replicated experiments were

150 conducted.

151 Samples collected from sites with water temperatures of 17.3 to $24.2^{\circ} \mathrm{C}$ were stored

152 at room temperature $\left(22 \pm 1^{\circ} \mathrm{C}\right)$ until trials began, whereas samples collected from cold

153 water sites $\left(5.0\right.$ to $\left.15.0^{\circ} \mathrm{C}\right)$ were placed in an environmental chamber at $11^{\circ} \mathrm{C}$.

154 Experiments began no more than 24 hours after sample collection and invertebrates 
were not fed during this interval. Treatment brine concentrations were produced by diluting stock brine (300\%; Pollard Highway Products, Harrow, ON, Canada) with filtered site water; final concentrations were checked using an optical or digital refractometer. Experiments were initiated by filtering a randomly drawn subsample through a $40 \mu \mathrm{m}$ sieve and rinsing retained invertebrates into a counting tray with $\sim 80 \mathrm{~mL}$ of diluted brine at a pre-determined treatment concentration or filtered site water (control). The volume of filtrate was dependent on animal density, with a target of $\geq 50$ individuals per replicate for ballast tank and Detroit River experiments and $\geq 100$ individuals per replicate for North Sea experiments. The number of individuals and taxonomic composition of each replicate was subject to random variation. Four replicates were set up for each treatment and control, with the exception of ballast tank trials and the Detroit River trial at $22^{\circ} \mathrm{C}$, for which five replicates were used. Invertebrate survival was assessed hourly in each replicate by viewing individuals under a Leica dissecting microscope at 10-80x magnification. Invertebrates that did not exhibit any movement, even in reaction to stimulation with a dissection probe, were considered dead. When all individuals in all replicates of a treatment appeared dead, brine exposure was ended. Individuals were then transferred to filtered site water for one hour to allow possible recovery, and then reassessed. If living individuals were found after the recovery period, survival rates for earlier time periods were adjusted to correct for later, higher, survival rates. Due to time constraints, at each observation time point, control groups were counted to determine the number of dead individuals in each tray whereas treatment groups were counted to determine the number of live individuals in each tray; at the termination of each trial, samples were preserved in $95 \%$ ethanol 
and counted in entirety to enable the calculation of percent mortality. Exposure times varied between one hour and six days due to variation in brine tolerance of taxa. Water samples from each replicate were tested to ensure that treatment concentration and temperature were maintained until the experiment was ended. Taxonomic identification was conducted for all individuals from ballast water experiments. Additionally, fixedcount sampling techniques were employed to subsample 100 individuals from each North Sea and Detroit River trial to identify to genus level (Barbour and Gerritsen, 1996). For North Sea trials, individuals surviving brine treatment were preserved separately, allowing for identification of resistant taxa. Invertebrates were identified using Koste (1978), Balcer et al. (1984), Barnes (1994), Hayward and Ryland (1995), Johnson and Allen (2005), Bartsch (2006), and Newell and Newell (2006); taxa from at least 37 genera were included in trials.

\subsection{Data Analysis}

Survival rates from brine exposure experiments were calculated as the proportion of individuals alive when brine exposure was ended. The number of dead individuals found in treatment groups may be attributed to individuals dead at the beginning of testing, individuals that died naturally during the test, or individuals that died as a result of brine exposure. To accurately report the mortality caused by brine treatment alone, it was necessary to exclude from analysis individuals that died from the former two sources. Survival rate to brine treatment was calculated as:

$$
\text { Survival rate }(\%)=T S / C S \times 100 \% \quad \text { Equation } 1
$$

where $T S$ is the number of viable individuals / total number of individuals in the treatment $(15 \%, 30 \%, 60 \%, 77 \%, 115 \%$ ) and CS is the number of viable individuals / 
201

202

203

204

total number of individuals in the control (filtered site water) at a given point in time (Abbott, 1925). In cases where this equation yielded a survival rate greater than 100 , this value was reduced to 100 for further analysis.

For statistical analysis, any replicate, or taxonomic group within a replicate, that had less than 10 individuals was excluded. Kruskal-Wallis tests were performed to determine if survival rates for different brine treatments or different treatment temperatures varied significantly (Zar, 1999). Kruskal-Wallis tests were also used to determine if there was a difference in survival to brine treatment based on an individual's life history (collection salinity, taxonomic affiliation). Wilcoxon rank sum tests were used to perform pair-wise comparisons of variables found to be significantly different using a Kruskal-Wallis test. A significance level of $95 \%$ was used for all analyses, except in cases where multiple tests were conducted on the same dataset, in which case a Bonferroni correction was applied. All tests, with the exception of one, compared experiments with an equal number of replicates; for the exception, one replicate was randomly excluded from analysis. It was not possible to test for a difference in survival due to temperature after exposure to $60 \%$ brine, because there were differences amongst experiments within treatments (see 3.4).

\section{Results}

\subsection{Taxonomic Affiliation}

Invertebrates tested were grouped as copepods, copepod nauplii, rotifers, and "other" taxa. Taxa in the "other" group included Cladocera (including, but not limited to, Bosmina spp., Leptodora spp., and Diaphanosoma spp.), Gastropoda and their larvae, 
Halacaridae, Insecta, Mysida, Nanorchestidae, Noctilucaceae, Polychaeta, and Protista. Nauplii of Cirripedia were present in three trials at high abundance, and were considered a separate group in these trials. There was a significant difference in survival amongst taxonomic groups at $77 \%$ o and $115 \%$ brine treatments (Fig. 1 ; KruskalWallis, $p<0.001$ ), but not at the $60 \%$ o concentration ( $p>0.05)$. For both $77 \%$ and $115 \%$ treatments, significantly more Cirripedia larvae survived than copepods, copepod nauplii, or rotifers (Wilcoxon rank sum test with Bonferroni correction, $\mathrm{p}<0.015$ ), and

231 survival of "other" species did not differ from that of other groups (Wilcoxon rank sum 232 test with Bonferroni correction, $p>0.04)$.

\section{$233 \quad 3.2 \mathrm{NaCl}$ brine toxicity}

234 Survival decreased with increasing brine concentration. The median survival rate

235 for Detroit River invertebrates exposed to three hours of $15 \%$ o brine treatment was 0.00\% (range 0.00-29.82) (Fig. 2), whereas all Detroit River invertebrates died after one

237 hour of exposure to $30 \%$ or $60 \%$ brine treatment (322 individuals) (Fig. 2a). For all 238 invertebrates tested, the median survival rate after one hour of treatment with $60 \%$ o 239 brine, $77 \%$ o brine, or $115 \%$ brine was $0.00 \%$. However, there were important differences 240 in the range of survival rates observed, which reflects variability in the consistency of 241 treatment efficacy. One hour of $60 \%$ o brine treatment resulted in survival rates between $2420 \%$ and $100 \%$ (Fig. 2), whereas after two hours of exposure, survival rates were 243 between $0.00 \%$ and $4.36 \%$ (Fig. 2). Survival rates between $0.00 \%$ and $12.09 \%$ were 244 seen for $77 \%$ o brine treatment, and survival rates between $0.00 \%$ and $5.33 \%$ were seen 245 for $115 \%$ brine treatment. Survival rates for $60 \%$ are not directly comparable to results 246 from $77 \%$ and $115 \%$ o treatments, since they were not generated from the same 
experiments (see Table 1). A total of 126 of 13188 individuals tested $(<0.01 \%)$ survived exposure to $77 \%$ orine, whereas only five of 13183 individuals tested (3.79\%) survived exposure to $115 \%$ orine. Significantly greater mortality occurred with exposure to $115 \%$ than in $77 \%$ o brine in four experiments (Fig. 3; Kruskal-Wallis, $p<0.05$ ). There was no significant difference in survival for ballast tank invertebrates exposed to $60 \%$ or $77 \%$ 。 brine (Fig. 2c; Kruskal-Wallis, p>0.15).

\subsection{Temperature}

The effect of brine exposure was examined at $22^{\circ} \mathrm{C}$ and $11^{\circ} \mathrm{C}$ for all ballast tank and Detroit River trials. Although two copepod nauplii survived $115 \%$ o brine treatment at $11^{\circ} \mathrm{C}$ and zero individuals survived the treatment at $22^{\circ} \mathrm{C}$, the difference was not statistically significant. In fact, there was no significant difference in survival rates between the two temperatures for any of the treatment concentrations tested (Fig. 4; Kruskal-Wallis, $\mathrm{p} \geq 0.05$ ).

\subsection{Source Habitat Salinity}

Taxa collected from freshwater habitats were much more susceptible to brine treatment than those from either brackish or marine habitats. No freshwater taxa survived one hour of $30 \%$ brine treatment (Fig. 2a), whereas some individuals of brackish and marine taxa survived treatment with $60 \%$, $77 \%$ o and $115 \%$ o brine (Figs. $2 \mathrm{~b}$, 2c). Furthermore, survival after one hour of $77 \%$ o brine treatment was significantly 266 greater for individuals from 20 to $22 \%$ o habitats than for those from 1 to $9 \%$ o habitats 267 (Fig. 3; Kruskal-Wallis, $\mathrm{p}<0.001$; Wilcoxon rank sum test with Bonferroni correction, $268 \mathrm{p}<0.005)$. There was no difference in survival of taxa from different habitats after one 269 hour of $115 \%$ o brine treatment (Kruskal-Wallis, $p>0.05$ ). 


\subsection{Identification of Survivors}

98 individuals in North Sea trials and 17 individuals in ballast tank trials survived one hour of $77 \%$ brine treatment. These survivors were 93 Cirripedia nauplii, four copepod nauplii, one Nanorchestes sp., one Rhombognathides sp., one Nereis sp., and 15 unidentified individuals. The median survival rate for Cirripedia nauplii was 2.06\% (range $0.00-12.21$ ) for this treatment. Five individuals, including two Cirripedia nauplii, two copepod nauplii, and one Nanorchestes sp., survived one hour of $115 \%$ o brine treatment. The median survival rate for Cirripedia nauplii was $0.00 \%$ (range $0.00-0.09$ ) in this treatment.

\section{Discussion}

This study indicates that treatment with $115 \% \circ \mathrm{NaCl}$ brine for one hour can be a rapid and effective strategy for emergency management of residual ballast water to prevent the introduction of nonindigenous invertebrate species to the Great Lakes. While one hour treatment with $77 \%$ and $115 \%$ o brine were both very effective (>99\% mortality) against all taxa examined, $115 \%$ o treatment was statistically more effective in several trials and yielded complete mortality more frequently, making this management option more preferable.

\section{The effect of temperature on treatment efficacy was explored to ensure} meaningful results irrespective of season, because the effects of salinity changes on aquatic taxa can be modulated by temperature (Kinne, 1963; Browne and Wanigasekera, 2000) and surface water temperature may vary between $0^{\circ}$ and $27^{\circ} \mathrm{C}$ when international ships are active on the Great Lakes (Reid and Orlova, 2002). At the 
brine concentrations examined here, survival was not significantly affected by temperature and thus brine treatment is expected to be effective throughout the shipping season. Since a species' salinity tolerance is influenced by the salinity of its natural habitat (Costlow et al., 1966; Laughlin and Neff, 1981; Fockedey et al., 2005), our experiments included invertebrates collected from salinities between $0 \%$ and $34 \%$ 。 to determine if all taxa arriving to the Great Lakes via ballast water would be susceptible to brine treatment. Mortality was not influenced by habitat salinity when taxa were treated with $115 \%$ o brine, providing further evidence for the broad efficacy of this treatment. $77 \%$ o brine treatment is not as broadly effective since taxa collected from 20 to $22 \%$ habitats survived this treatment significantly better than did those collected from 1 to $9 \%$ environments. However, these results show that taxa in ballast tanks that originate from habitats with low salinity - which would pose the greatest establishment threat to the Great Lakes - are the least likely to survive exposure to brine treatment. The most resistant taxon to brine treatment was Cirripedia nauplii. Cirripedia nauplii are only infrequently observed and at very low density in residual ballast samples and therefore pose a relatively low risk for introduction to the Great Lakes (Duggan et al., 2005). Additionally, even if Cirripedia was introduced to the Great Lakes, it is a marine taxon that is not expected to survive in freshwater habitats. In fact, a comprehensive study on hull fouling found that Cirripedia were always dead or in poor condition when attached to ship hulls in the Great Lakes, presumably due to exposure to freshwater (Sylvester and Maclsaac, 2010).

We estimate that treatment using $115 \%$ o brine for one hour of exposure will be at least as effective as ballast water exchange, exterminating $>99 \%$ of marine, brackish 
and freshwater organisms from residual ballast water. However, Canadian regulations require that any ballast water treatment other than ballast water exchange or tank flushing must reduce concentrations of viable organisms and indicator microbes below a specified discharge standard. For aquatic invertebrates with a minimum dimension greater than or equal to $50 \mu \mathrm{m}$ (i.e., the invertebrates examined in this study), the relevant discharge standard is less than 10 viable individuals $\mathrm{m}^{-3}$ (Government of Canada, 2006; see also USCG (2009) and IMO (2004) for proposed equivalent American and International standards). Given a median survival rate of $0.00 \%$ (range $0.00-5.33$ ) and assuming a median density of 280 individuals $\mathrm{m}^{-3}$ in untreated residual ballast water (Duggan et al., 2005), treatment with 115\%。 brine for one hour is expected to result in a median density of 0 (range $0-15)$ individuals $\mathrm{m}^{-3}$. Therefore, our recommended treatment application is expected to achieve results that are largely compliant with the relevant discharge standard. Furthermore, taxa arriving in ballast water are likely in poor condition from transit, and may be more susceptible to unfavourable conditions than would the healthy port taxa tested here (Wonham et al., 331 2001).

While brine treatment at our recommended dosage appears highly effective, we acknowledge two limitations to our study. First, although ballast water may contain

334 many different taxa, mainly zooplankton were tested in these experiments. Zooplankton

335 were used as model organisms because they are abundant in ballast tanks, because

336 their viability can be assessed easily using light microscopy, and because the Great

337 Lakes have sustained many invasions by this group (e.g. Bythotrephes longimanus, 338 Cercopagis pengoi, Daphnia lumholtzi). However, discharge standards for ballast water 
regulate all aquatic taxa greater than $10 \mu \mathrm{m}$ in minimum dimension, as well as indicator microbes. Thus, it is necessary to consider a broader range of taxa when assessing brine treatment as results from zooplankton alone may not reflect efficacy against all biotic groups. It is known that $\mathrm{NaCl}$ concentrations $>10 \%$ o will eliminate most bacteria and $\mathrm{NaCl}$ concentrations $>30 \%$ o will be toxic to many fungi (Dr. Carol Litchfield, George Mason University, personal communication). Additionally, preliminary tests have shown that the round goby (Neogobius melanostomus), a previously introduced fish known to be susceptible to ballast water exchange (Ellis and Maclsaac, 2009), is killed by brine exposure of $45 \%$ o to $60 \%$ (Santagata et al., 2008). Therefore, although it requires empirical examination, we expect that non-halophilic taxa that are transported in ballast water will be negatively affected by brine treatment.

Second, our recommendations are based on laboratory, rather than ship-scale, trials. Laboratory studies were used to establish a 'proof of principle' and because they allowed us to manipulate variables that would not have been feasible in shipboard studies. Our recommendation of $115 \%$ treatment for one hour assumes complete mixing in tanks to achieve a uniform salinity. However, ballast tank structure is complex, with multiple longitudinal and transverse members that could restrict uniform application of brine to ballast residuals; higher survival rates would be expected if brine application is spatially heterogeneous. Ship-scale studies are required to determine if brine treatment will be equally effective under operational conditions.

Before implementation of this treatment, the environmental impact of releasing brine into the Great Lakes must be considered. Concern exists about the environmental consequences of road salt run-off entering waterways (d'Itri, 1992; Jones et al., 1992; 
362 Forman and Alexander, 1998) and because brine would be released into the Great

363 Lakes post-treatment, it could contribute to the problem. Residual ballast typically

364 amounts to less than $0.5 \%$ of tank capacity ( 10 tonnes), so only small volumes of brine

365 ( 10 tonnes) would be required to conduct $115 \%$ o treatment. As a result, the treated tank

366 could (and should) be filled with Great Lakes water before discharge to dilute the brine

367 to concentrations $\leq 10 \%$. The brine is expected to be further diluted by at least a factor

368 of 10 with discharge, so the impact of brine treatment should be minimal and spatially

369 localized.

3704 Conclusions

371 One-hour treatment of $115 \%$ obrine exterminated nearly all invertebrate ballast

372 water taxa (>99.99\%) in laboratory trials. Survival is not affected by temperature,

373 species' habitat salinity, or by taxonomic affiliation. Post-treatment densities of viable

374 invertebrates comply with relevant Canadian and proposed international discharge

375 standards and should be at least as effective as current ballast water management

376 practices of vessels entering the Great Lakes.

\section{Acknowledgements}

This project was funded by Transport Canada, Fisheries and Oceans Canada,

380 and the NSERC Canadian Aquatic Invasive Species Network (CAISN). We thank M.

381 Deneau, C. Simpkins, F. Sylvester, M. Whitehead, C. van Overdijk, S. Ellis, and O.

382 Raza for assistance in the field and laboratory. We also thank M. Orbons and M.

383 Versteeg for help with North Sea sampling and trials. H. Proctor and I. Bartsch provided 
assistance with taxonomic identifications, and J.C. Barrette and B. Middleton assisted with metals analysis.

\section{References}

Abbott, W.S., 1925. A method for computing the effectiveness of an insecticide. J. Econ. Entomol. 18, 265-267.

Balcer, M.D., Korda, N.L., Dodson, S.I., 1984. Zooplankton of the Great Lakes: A guide to the identification and ecology of the common crustacean species. University of Wisconsin Press, Madison.

Barbour, M.T., Gerritsen, J., 1996. Subsampling of benthic samples: A defense of the fixed-count method. J. N. Am. Benth. Soc. 15, 386-391.

Barnes, R.S.K., 1994. The brackish-water fauna of northwestern Europe: An identification guide to brackish-water habitats, ecology and macrofauna for field workers, naturalists and students. Cambridge University Press, Cambridge.

Bartsch, I., 2006. Halacaroidea Acari.: a guide to marine genera. Org. Divers. Evol. 6, 103-108.

Browne, R.A., Wanigasekera, G., 2000. Combined effects of salinity and temperature on survival and reproduction of five species of Artemia. J. Exp. Mar. Biol. Ecol. 244, $29-44$

Carlton, J.T., 1985. Trans-oceanic and interoceanic dispersal of coastal marine organisms - the biology of ballast water. Oceanogr. Mar. Biol. 23, 313-371.

Colautti, R.I., Niimi A.J., van Overdijk, C.D.A., Mills E.L., Holeck, K., Maclsaac, H.J., 2003. Spatial and temporal analysis of shipping vectors to the Great Lakes. In: Ruiz, 
G.M., Carlton, J.T., Mack, R.N. (Eds.), Invasion pathways: Analysis of invasion patterns and pathway management, pp. 227-246, Island Press, Washington, D.C.

409 Costlow, J.D., Bookhout, C.G., Monroe, R., 1966. Studies on the larval development of

410 the crab, Rhithropanopeus harrisii Gould. I. The effect of salinity and temperature on

411 larval development. Physiol. Zool. 61, 81-100.

412 d'Itri, F.M. (Ed.), 1992. Chemical Deicers and the Environment. Lewis Publishers,

413 Chelsea, MI, USA.

414 Duggan, I.C., van Overdijk, C.D.A., Bailey, S.A., Jenkins, P.T., Limén, H., Maclsaac,

415 H.J., 2005. Invertebrates associated with residual ballast water and sediments of 416 cargo-carrying ships entering the Great Lakes. Can. J. Fish. Aquat. Sci. 62, 24634172474.

418 Ellis, S., Maclsaac, H.J. 2009. Salinity tolerance of Great Lakes invaders.

$419 \quad$ Freshwater Biol. 54, 77-89.

420 Fockedey, N., Mees, J., Vangheluwe, M., Verslycke, T., Janssen, C.R., Vincx, M., 2005.

421 Temperature and salinity effects on post-marsupial growth of Neomysis integer

$422 \quad$ Crustacea: Mysidacea.. J. Exp. Mar. Biol. Ecol. 326, 27-47.

423 Forman, R.T.T., Alexander, L.E., 1998. Roads and their major ecological effects. Ann.

$424 \quad$ Rev. Ecol. Syst. 29, 207-231.

425 Government of Canada, 2006. Ballast water control and management regulations.

426 Canada Gazette 140 (13), SOR/2006-129.

427 Gray, D.K., Johengen, T.H., Reid, D.F, Maclsaac, H.J., 2007. Efficacy of open-ocean 428 ballast water exchange as a means of preventing invertebrate invasions between 429 freshwater ports. Limnol. Oceanogr. 52, 2386-2397. 
Hart, B.T., Bailey, P., Edwards, R., Hortle, K., James, K., McMahon, A., Meredith, C., Swadling, K., 1991. A review of the salt sensitivity of the Australian freshwater biota. Hydrobiologia 210, 105-144.

Hayward, P.J., Ryland, J.S. (Eds.), 1995. Handbook of the Marine Fauna of North-West Europe, Oxford University Press, Oxford, Great Britain.

Hovanec, T.A., Coshland, J.L., 2004. A chemical analysis of select trace elements in synthetic sea salts and natural seawater. Advanced Aquarist Online (http://advancedaquarist.com/issues/sept2004/feature.htm).

International Maritime Organization, 2004. International convention for the control and management of ships' ballast water and sediments. Adopted 13 February 2004. Jenkins, P.T., 2007. Brine as a treatment solution for the control of aquatic nuisance species introductions into the great lakes by NOBOB vessels. Transport Canada T8275-05-0249. Technical Report. Transport Canada-Marine Safety, Ottawa, ON. Johnson, W.S., Allen, D.M., 2005. Zooplankton of the Atlantic and Gulf Coasts: A guide to their identification and ecology. Johns Hopkins University Press, Baltimore. Jones, P.H., Jeffrey, B.A., Watler, P.K., Hutchon, H., 1992. Environmental impact of road salting. In: d'Itri, F. M. (ed.) Chemical Deicers and the Environment. Lewis Publishing, Chelsea, MI, pp. 1-116.

Kefford, B.J., Palmer, C.G., Pakhomova, L., Nugegoda, D., 2004. Comparing test systems to measure the salinity tolerance of freshwater invertebrates. Water SA, 30, 499-506. 
451 Kinne, O., 1963. The effects of temperature and salinity on marine and brackish water

452 animals. In: Barnes, H. (ed.) Oceanography and marine biology: An annual review.

$453 \quad$ Unwin Brothers Limited, London, pp 301-340.

454 Koste, W. [ed.] 1978. Rotatoria. Gebrüder Bortraeger, Berlin.

455 Laughlin, R.B.Jr., Neff, J.M., 1981. Ontogeny of respiratory and growth responses of

456 larval mud crabs Rhithropanopeus harrisii exposed to different temperatures,

457 salinities and naphthalene concentrations. Mar Ecol-Prog. Ser. 5, 319-332.

458 Locke, A., Reid, D.M., van Leeuwen, H.C., Sprules, W.G., Carlton, J.T., 1993. Ballast

459 water exchange as a means of controlling dispersal of freshwater organisms by

460 ships. Can. J. Fish. Aquat. Sci. 50, 2086-2093.

461 Maclsaac, H.J., Robbins, T.C., Lewis, M.A., 2002. Modelling ships' ballast water as

462 invasion threats to the Great Lakes. Can. J. Fish. Aquat. Sci. 59, 1245-1256.

463 Minton, M.S., Verling, E., Miller, A.W., Ruiz G.M., 2005. Reducing propagule supply and

464 coastal invasions via ships: Effects of emerging strategies. Front. Ecol. Environ. 3,

$465 \quad 304-308$.

466 Newell, G.E., Newell, R.C., 2006. Marine plankton. Hutchinson Educational, London.

467 Reid, D.F., Orlova, M., 2002. Geological and evolutionary underpinnings for the success

468 of Ponto-Caspian species invasions in the Baltic Sea and North American Great

469 Lakes. Can. J. Fish. Aquat. Sci. 59, 1144-1158.

470 Ricciardi, A., Maclsaac, H.J., 2000. Recent mass invasion of the North American Great $471 \quad$ Lakes by Ponto-Caspian species. Trends Ecol. Evol. 15, 62-65. 
472 Rigby G.R., Hallegraeff G.M., Sutton C., 1999. Novel ballast water heating technique

473 offers cost-effective treatment to reduce the risk of global transport of harmful marine

474 organisms. Mar. Ecol-Prog. Ser. 191, 289-293.

475 Santagata, S. Gasiunaite, Z.R., Verling, E., Cordell, J.R., Eason, K., Cohen, J.S.,

476 Bacela, K., Quilez-Badia, G., Johengen, T.H., Reid, D.F., Ruiz, G.M., 2008. Effect of

477 osmotic shock as a management strategy to reduce transfers of non-indigenous

478 species among ports by ships. Aquatic Invasions, 3, 61-76.

479 Santagata S., Bacela, K., Reid, D., McLean, K.A., Cohen, J.S., Cordell, J.R., Brown,

480 C.W., Johengen, T.H., Ruiz, G.M., 2009. Concentrated sodium chloride brine

481 solutions as an additional treatment for preventing the introduction of nonindigenous

482 species in the ballast tanks of ships declaring no ballast on board. Environ. Toxicol.

$483 \quad$ Chem. 28, 346-353.

484 Schlieper, C., 1971. Part II: Physiology of brackish water, in: Remane A., Schlieper, C,

485 Biology of brackish water. Wiley Interscience, Stuttgart, pp. 211-321.

486 Sylvester, F. and Maclsaac, H. 2010. Is vessel hull fouling an invasion threat to the

487 Great Lakes?. Divers. Distrib. 16, 132-143.

488 Turekian, K.K., 1968. Oceans. Prentice-Hall, New Jersey.

489 United States Coast Guard, 2009. Proposed ballast water discharge standard

$490 \quad$ rulemaking. USCG-2001-10486. (http://www.regulations.gov)

491 Wonham, M.J., Walton, W.C., Ruiz, G.M., Frese, A.M, Galil, B.S., 2001. Going to the

492 source: role of the invasion pathway in determining potential invaders. Mar. Ecol-

493 Prog. Ser. 215, 1-12.

494 Zar, J.H. 1999. Biostatistical Analysis, Prentice-Hall, New Jersey. 
495 Table 1. Number of trials conducted for each temperature $\mathrm{x}$ brine concentration 496 combination, by sample source location. Sample source locations: T- ballast tank 497 that has undergone ballast water exchange; D- Detroit River; A= Port of Antwerp; 498 R- Port of Rotterdam; B=Port of Bremen; N- Waal River, Nijmegen.

\begin{tabular}{|c|c|c|c|c|c|c|c|c|c|c|}
\hline & \multicolumn{5}{c|}{$11{ }^{\circ} \mathrm{C}$} & \multicolumn{7}{c|}{$22^{\circ} \mathrm{C}$} \\
Sample & 15 & 30 & 60 & 77 & 115 & 15 & 30 & 60 & 77 & 115 \\
\hline $\mathrm{T}$ & & & 3 & 3 & 3 & & & 2 & 2 & 2 \\
\hline $\mathrm{D}$ & 1 & 1 & 1 & & & 1 & 1 & 1 & & \\
\hline $\mathrm{A}$ & & & & & & & & & 3 & 3 \\
\hline $\mathrm{R}$ & & & & & & & & & 5 & 5 \\
\hline $\mathrm{B}$ & & & & & & & & & 1 & 1 \\
\hline $\mathrm{N}$ & & & & & & & & & 1 & 1 \\
\hline
\end{tabular}

499 


\section{$500 \quad$ Figure Legends}

501 Figure 1. Mean (+SD) survival rate for copepods (black bars), copepod nauplii

502 (open bars), rotifers (vertically striped bars), "other" taxa (grey bars), and

503 Cirripedia nauplii (diagonally striped bars) exposed to one hour of $\mathrm{NaCl}$ brine.

504 Median values greater than 0 are indicated by horizontal lines. $\left(^{*}\right)$ indicates

505 statistically significant difference in survival between groups. Survival rates have

506 been corrected to account for mortality in controls (see 2.3).

508 Figure 2. Mean (+SD) survival rate for $(A)$ freshwater, $(B)$ North Sea, and (C)

509 ballast water organisms exposed to $\mathrm{NaCl}$ brine. Median value is zero for all bars.

510 Survival rates have been corrected to account for mortality in controls (see 2.3).

512 Figure 3. Mean (+SD) survival rate for organisms exposed to one hour of $77 \%$

513 (solid bar) or $115 \%$ (open bar) $\mathrm{NaCl}$ brine treatment. Each pair of bars

514 represents a separate trial conducted at a given habitat salinity. Median values

515 greater than 0 are indicated by horizontal white lines (77\%) and black lines

516 (115\%॰). $\left(^{*}\right)$ indicates statistically significant lower survival in $115 \%$ o treatment

517 than in $77 \%$ o treatment. Survival rates have been corrected to account for

518 mortality in controls (see 2.3).

520 Figure 4. Mean (+SD) survival rate for $(A)$ freshwater, and $(B)$ ballast water

521 organisms exposed to $\mathrm{NaCl}$ brine treatment at $2^{\circ} \mathrm{C}$ ( solid bar) and $11{ }^{\circ} \mathrm{C}$ (open

522 bar). Median values greater than 0 are indicated by white lines $\left(22^{\circ} \mathrm{C}\right)$ and black 
523 lines $\left(11^{\circ} \mathrm{C}\right)$. Exposure time is one hour unless conc entration is marked with an $\S$ 524 (3 hours). Survival rates have been corrected to account for mortality in controls 525 (see 2.3). The effect of temperature on survival rate was found to be statistically 526 insignificant. 


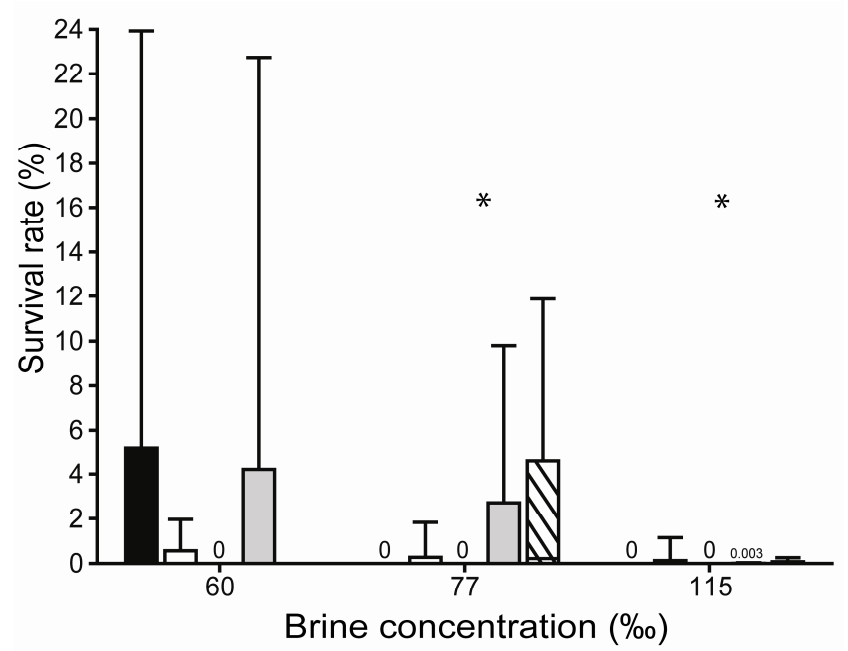




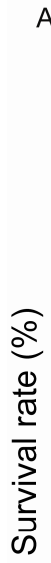

A)

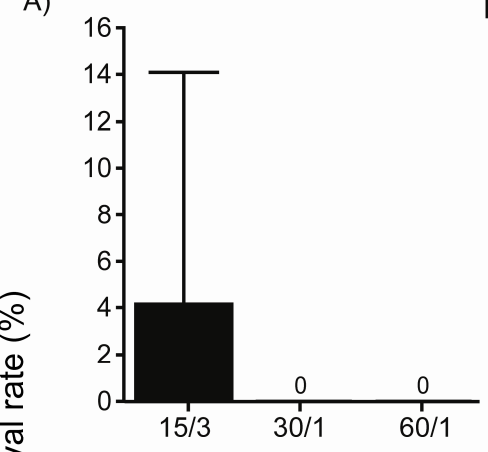

B)

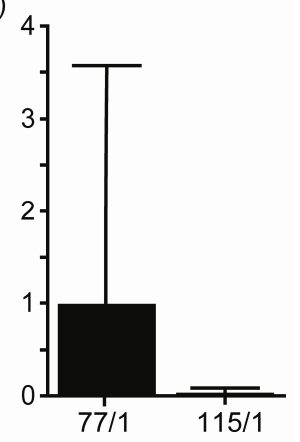

C)

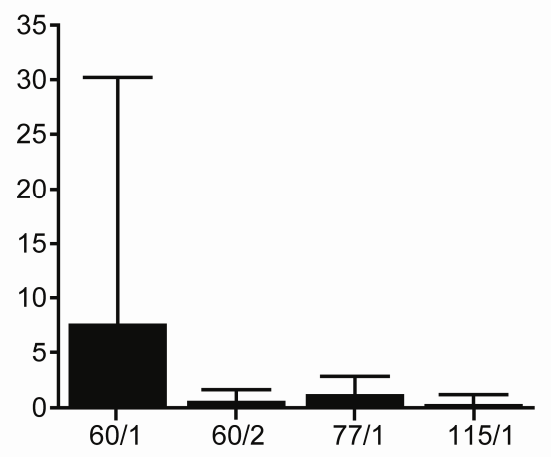

Brine concentration (\%o) / Exposure time (h) 


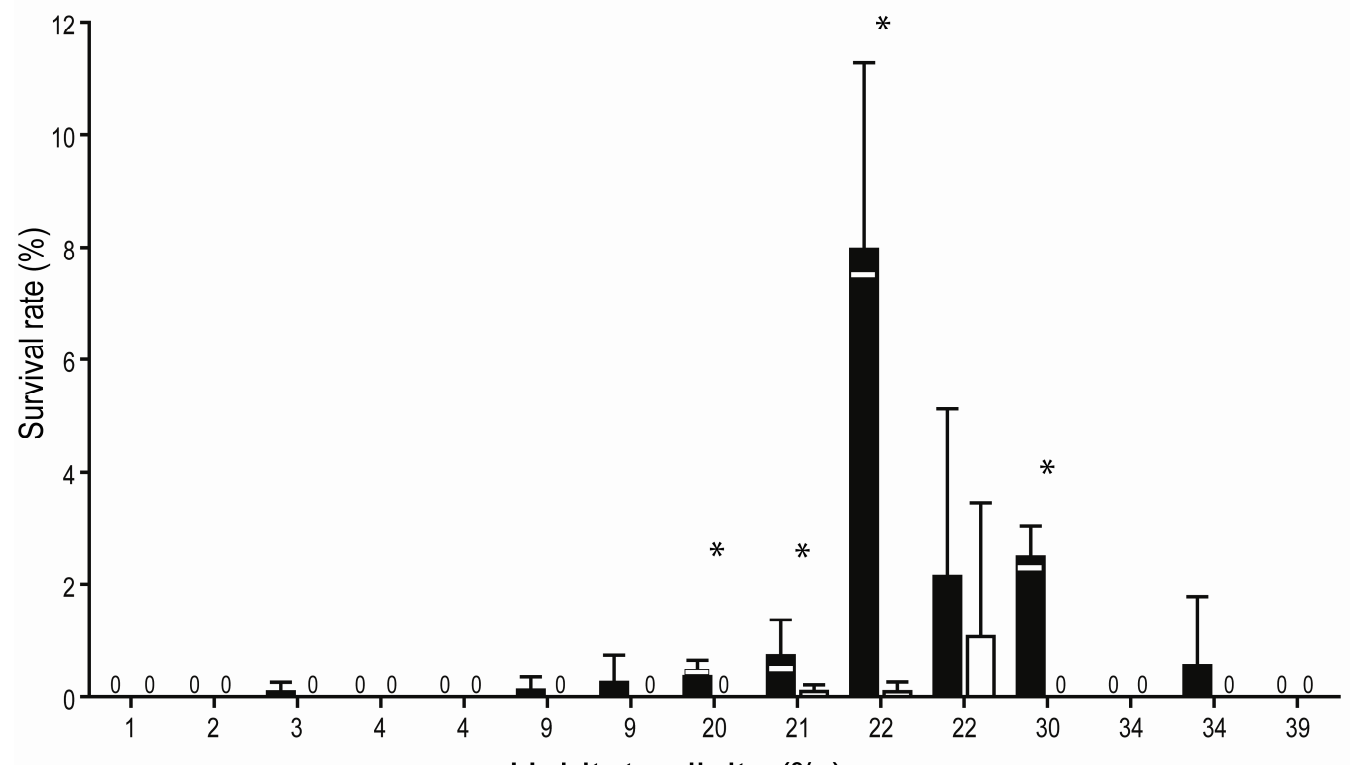

Habitat salinity $(\% \circ)$ 


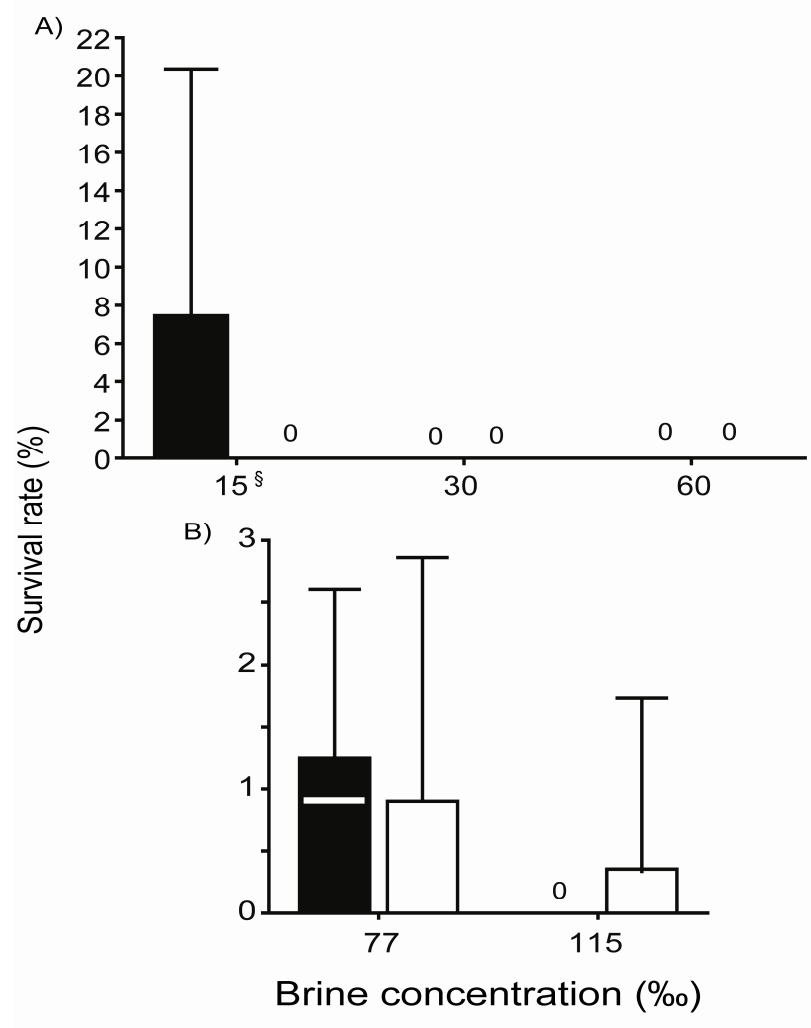

